\title{
Development of sustainable compositions and study of the properties of porous aggregates from the waste of a mining and processing plants
}

\author{
Yevhen Liulchenko ${ }^{1 *}$, Serhiy Sakhno ${ }^{1}$, Tetiana Sergiienko ${ }^{2}$, and Maxim Sergiienko ${ }^{2}$ \\ ${ }^{1}$ Kryvyi Rih National University, Civil Engineering Faculty, 11 Vitalii Matusevych Str., Kryvyi Rih, 50027, Ukraine \\ ${ }^{2}$ Sergiienko LLC 2215 Cropsey Ave D4, Brooklyn, NY 11214, USA
}

\begin{abstract}
In connection with the growing need for saving natural resources used in aggregates for concrete, the importance of lightweight structural aggregates obtained from production waste is continuously increasing. Lightweight structural concretes on porous aggregates can significantly reduce own weight of structures, make it possible to manufacture larger structures, reduce transport costs, and improve the thermal insulation and acoustic properties of enclosing structures. The use of waste from the mining and metallurgical industry to produce construction materials significantly reduces environmental pollution. The article is devoted to studying the possibility of using wastes from the mining and processing industry of enterprises of the Kryvyi Rih iron ore basin to produce lightweight porous aggregate. The paper presents the results of studies of the effect of the charge's granulometric composition, the quantitative content of the raw mix components, and the temperature of heat treatment on aggregate quality. The most suitable raw material mixture for artificial aggregate has been determined. The results of X-ray diffraction thermographic analysis of raw granules are presented. The influence of technological factors on the aggregate density and strength has been studied using mathematical modeling. The obtained equations made it possible to reveal the regularities of the raw mixture's components and temperature for the optimal aggregate density and strength. The results of studying the structure and porosity of the developed aggregate are presented. The results of X-ray thermographic analysis of the aggregate explain the mechanism of pore formation in the pellets. The basic physical and mechanical properties of the obtained aggregate are investigated, particularly attention pairing to the study of the aggregate's contact zone with the cement stone.
\end{abstract}

\section{The problem and its relationship with scientific and practical tasks}

One of the main tasks in sustainable construction development is reducing the mass of buildings and structures. One way to solve this problem is to use lightweight and lightweight concrete on porous aggregates. Despite the constant increase in lightweight concrete structures, their share does not exceed $30 \%$ of reinforced concrete volume.

The need to expand the production of lightweight concrete products is due to the ability to reduce the mass of buildings by $30-40 \%$, reduce the construction time by $20 \%$, reduce transport costs by $30-40 \%$, and significantly improve the thermal and acoustic properties of enclosing structures [1-5]. The considered advantages can significantly reduce the consumption of resources for constructing buildings and reduce the number of harmful emissions into the environment.

There are practically no areas of construction where porous aggregate concrete cannot successfully replace heavy concrete. Traditionally, lightweight concrete using as thermal insulation and structural-thermal insulation materials. However, in the total volume of building structures, enclosing structures make up only $25-30 \%$, and load-bearing systems $-70-75 \%$; therefore, the need to expand structural concrete production with porous aggregates are put forward in the first place. The release of load-bearing structures from lightweight and lightweight concrete is primarily constrained by the absence or shortage of suitable and durable porous aggregates. Most of the porous aggregates are used only for the production of building envelopes. Therefore, artificial porous aggregates from local raw materials significantly waste from the mining and metallurgical industries are of exact importance.

Mining and processing plants of Ukraine annually

* Corresponding author: lev1351ua@gmail.com 
store more than 130 million $\mathrm{m}^{3}$ of sludge. Only in the Kryvyi Rih iron ore basin, more than 2 thousand hectares of agricultural land are occupied by dumps. Part of the enrichment waste, with a particle size of more than $0.14 \mathrm{~mm}$, is used as a sand and crushed stone. However, a significant amount of waste has a particle size of less than $0.14 \mathrm{~mm}$, not currently used. Therefore, developing a technology for obtaining sustainable porous aggregates for concretes using finely dispersed waste from mining and processing plants and concretes based on them continues to be an urgent scientific, technical, and social task.

\section{Development of charge compositions and heat treatment mode}

The research aims to develop optimal compositions of new porous aggregates made from the waste of mining and processing plants and study these aggregates' properties.

The selection of the optimal composition of raw materials for the porous filler included an analysis of the influence of the charge and additives' design and their granulometric composition on the final product's quality.

Dry mixtures contained:

- crushed and not crushed sludge (grains with a size of $1.25 \ldots 0.14 \mathrm{~mm}$ );

- not crushed sludge with the addition of crushed shale;

- not crushed and crushed sludge with the addition of crushed shale;

- crushed sludge and crushed shale.

Dosing of the dry components of the charge carried out by weight. The content of crushed sludge and shale is taken as a percentage of the total dry ingredients. The content the rate of consumption of alkali silicate is taken from the total weight of the charge.

The mixture was granulated in a disk granulator to form granules with a diameter of $5 . . .20 \mathrm{~mm}$. Liquid glass is fed into the pelletizer using a spray gun.

The molding of the raw granules was carried out at different density values of alkali silicate $(1.30 \ldots 1.45$ $\mathrm{g} / \mathrm{cm}^{3}$ ), which provided the introduction of the required amount of its solid substance into the charge. This approach made it possible to reveal the pattern and nature of the influence of the consumption of alkali metal silicate on the porous filler's properties. Raw granules' burning was carried out at 950,1050 , and $1150^{\circ} \mathrm{C}$ for $5,10,15$, and 20 minutes. Further analysis of the results showed that firing longer than 10 minutes had no significant effect on the studied parameters.

The burnt granules' testing results from a raw mixture with crushed sludge in its proportion shown in Fig. 1. The obtained results show that if alkali silicate and the amount of ground sludge in the charge increases, the average density of aggregate granules decreases. However, it is impossible to obtain an aggregate with an average density of less than $1.5 \mathrm{~g} / \mathrm{cm}^{3}$ due to the resulting liquid phase's small amount. The amount of the liquid phase largely depends on the content of fine particles in the mixture. The amount of ground sludge did not exceed $20 \%$, and the larger grains did not take an active part in creating the pyroplastic melt; they dissolved only partially.

Adding a part of crushed shale to the slurry made it possible to obtain an aggregate with a lower average density than in the previous case. This dependence showed in Fig. 2. A decrease in filler granules' average density with the same fraction of the crushed charge (Fig. 1) occurs due to an increase in the liquid phase amount. This is because liquid glass forms more melting eutectics with shale minerals and more intense gas evolution occurs.

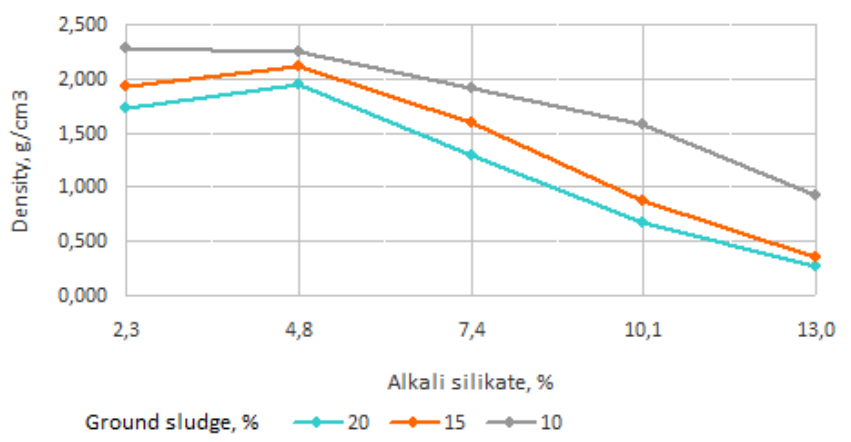

Fig. 1. Influence of the content of ground sludge and the flow rate of alkali silicate on the aggregate's front density.

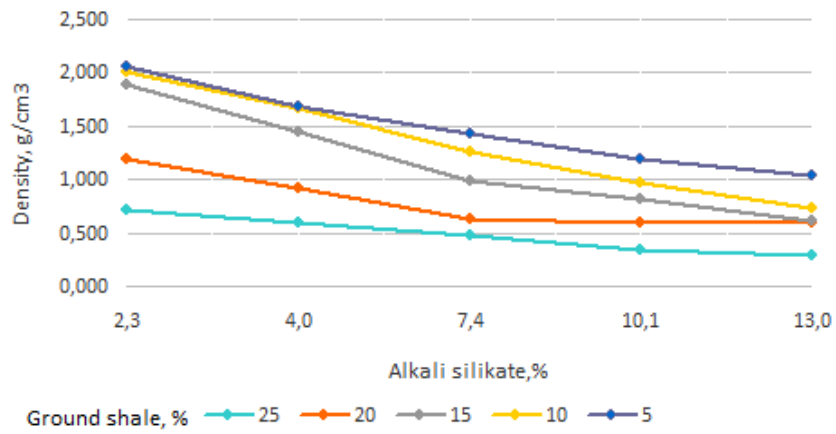

Fig. 2. Influence of ground shale and alkali metal silicate content on average aggregate density.

Studies have been carried out to study the content of crushed sludge and shale for the aggregate average density. These studies' results are shown in Fig. 3 and show that aggregate granules' average density decreases almost linearly, increasing alkali silicate consumption.

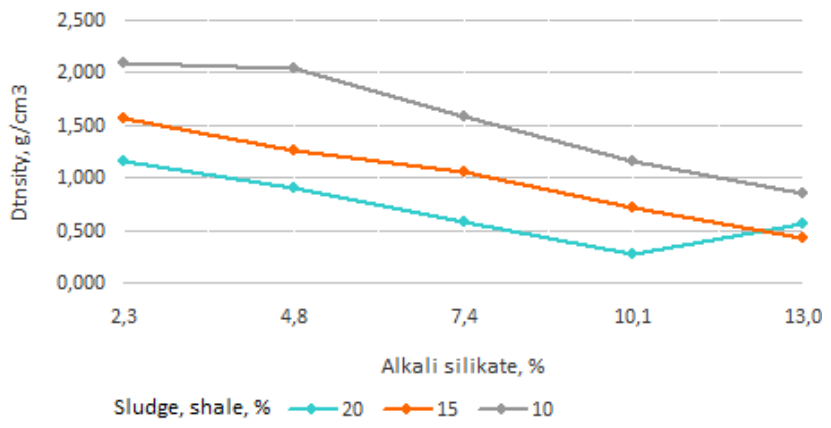

Fig. 3. Influence of the content of ground sludge, shale, and alkali silicate consumption on the average density of the aggregate. 
However, with a $15 \%$ content of crushed sludge, shale, and alkali silicate consumption of more than $10 \%$, an increase in aggregate granules' average density is observed. A decrease explains this in the melt's viscosity and the process of compaction rather than porization. The combined effect of the milled components on the aggregate granules' average density is greater than that of each separately.

Previous studies have shown that using a mixture containing unmilled sludge and shale results in lowstrength granules with low porosity and high average density. Therefore, all further studies were carried out only on mixtures with ground components. The results showed in Fig. 4 and 5.

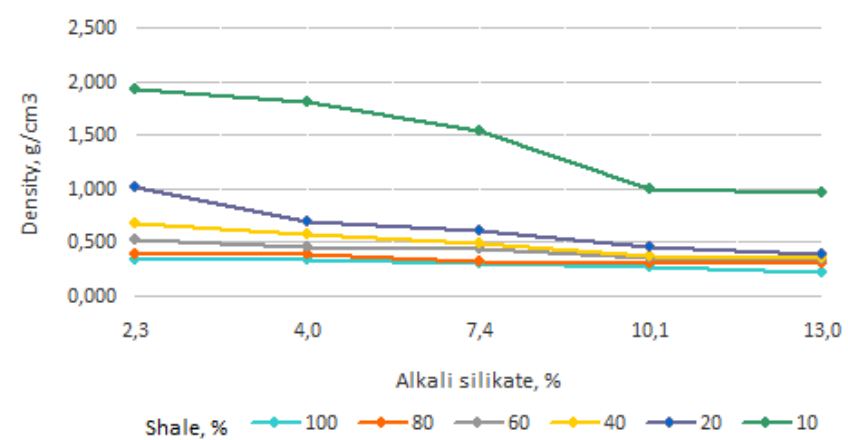

Fig. 4. The influence of alkali silicate consumption and the composition of the charge on the aggregate's average density.

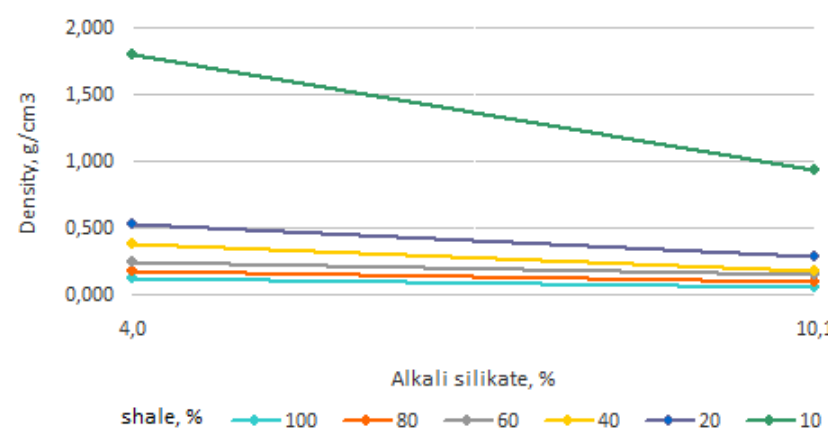

Fig. 5. Influence of the composition of the charge and the consumption of alkali silicate on the aggregate's average density.

Dependencies show that the most intensive decrease in average density occurs when there is up to $40 \%$ shale in the charge. A further increase in the shale amount reduces the average density slightly, but the granules' strength sharply decreases, and the pores increase due to increased gas release. Intense and excessive release of gaseous products does not improve the porization process but causes the formation of large interconnected pores, passing into cavities and open pores.

$\mathrm{X}$-ray phase analysis of raw granule powders, dried to constant weight, showed the presence of the following minerals:

- $\quad \beta-\mathrm{SiO}_{2}(\beta$-quartz);

$-\mathrm{FeFe}_{2} \mathrm{O}_{4}$;

$-\alpha-\mathrm{Fe}_{2} \mathrm{O}_{3}$

- $\mathrm{Al}_{2} \mathrm{O}_{3} \cdot 2 \mathrm{SiO}_{2} \cdot 2 \mathrm{H}_{2} \mathrm{O}-$ kaolinite;
- hydromica;

- $\mathrm{K}_{2} \mathrm{O} \cdot \mathrm{Al}_{2} \mathrm{O}_{3} \cdot 6 \mathrm{SiO}_{2}$ - potassium feldspar (orthoclase);

- $\mathrm{K}(\mathrm{Mg}, \mathrm{Fe})_{3}\left[\cdot \mathrm{AlSi}_{3} \mathrm{O}_{10}\right] \cdot(\mathrm{OH}, \mathrm{F})$;

- $\mathrm{K} \cdot \mathrm{Al}_{2} \cdot\left[\mathrm{AlSi}_{4} \mathrm{O}_{10}\right] \cdot(\mathrm{OH})_{2} \cdot \mathrm{nH}_{2} \mathrm{O}-$ illite;

- chlorites with an approximate composition of $\mathrm{Mg}_{5} \mathrm{Al} \cdot\left[\mathrm{AlSi}_{3} \mathrm{O}_{10}\right] \cdot(\mathrm{OH})_{8}$;

- $\mathrm{CaMg}\left(\mathrm{CO}_{3}\right)_{2}$ - dolomite;

Differential thermal analysis of raw granule powders showed (Fig. 6) the presence of endothermic effects at a maximum of $140,448,584$, and $772{ }^{\circ} \mathrm{C}$. The total weight loss upon calcination up to $800{ }^{\circ} \mathrm{C}$ was $8.11 \%$. The endothermic effect at a temperature of $140{ }^{\circ} \mathrm{C}$ is associated with removing adsorption water from clay minerals: kaolinite, monothermite, and illite close to kaolinite.

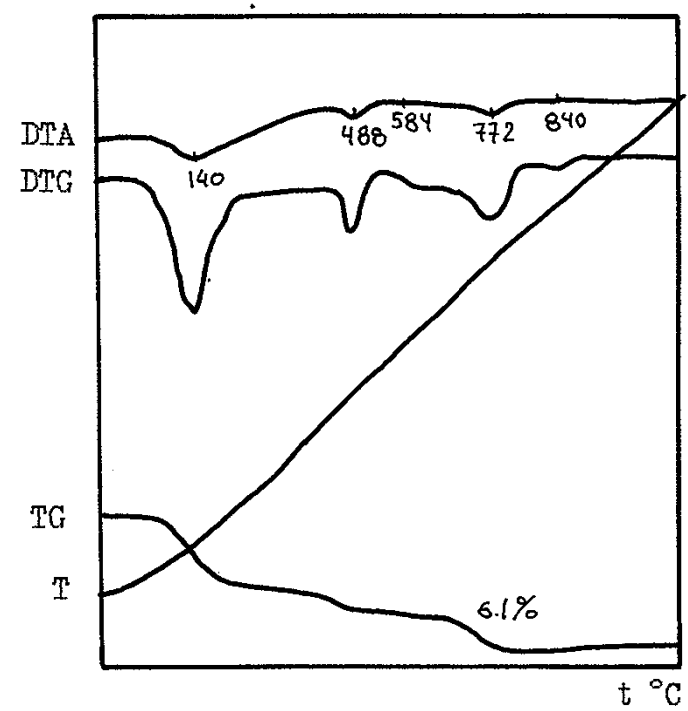

Fig. 6. Thermogram of raw granules.

The endothermic effect at a maximum temperature of $448^{\circ} \mathrm{C}$ is associated with removing constitutional water from the crystal lattice of minerals: kaolinite, monothermite, followed by the crystal lattice's destruction.

A small endothermic effect at a maximum temperature of $584^{\circ} \mathrm{C}$ is associated with removing constitutional water from the crystal lattice of minerals: illite, hydromica, and chlorite. The endothermic effect with a maximum of 772 ${ }^{\circ} \mathrm{C}$ is associated with dissociation of $\mathrm{CaCO}_{3}$ and dolomite and the destruction of chloride's crystal lattice.

The blurred endothermic effect at a maximum temperature of $840{ }^{\circ} \mathrm{C}$ is associated with destroying the crystal lattice of hydromica and illite.

Since previous studies have established that the most suitable for obtaining a porous aggregate is a crude mixture consisting of crushed sludge, crushed shale, and water glass, these mixtures have been used to study the influence of technological factors on the properties of the porous aggregate. The research objective is to obtain mathematical models expressing the aggregate's average density and strength on the leading technological factors. The mathematical planning method, followed by mathematical and statistical processing of the results, was used to reduce the number of experiments.

A three-factor experiment at two levels is planned in 
the work. The variables are $X_{1}-$ the content of ground shale as a percent of the total mass of dry components; $\mathrm{X}_{2}$ - consumption of liquid glass as a percent of the total mass of the charge; $\mathrm{X}_{3}$ - firing temperature ${ }^{\circ} \mathrm{C}$. Since firing for more than 10 minutes did not significantly affect the study's parameters, firing the granules was 10 minutes and not taken as a variable.

The levels and intervals of variation of the selected factors are shoved in the table. 1.

Table 1. Levels and intervals of variation.

\begin{tabular}{|l|c|c|c|c|}
\hline \multirow{2}{*}{\multicolumn{1}{c|}{ Code }} & \multirow{2}{*}{ Code value } & \multicolumn{3}{c|}{ Value of factors } \\
\cline { 3 - 5 } & & $\mathrm{X}_{1}$ & $\mathrm{X}_{2}$ & $\mathrm{X}_{3}$ \\
\hline Main level & 0 & 30 & 8.0 & 1050 \\
\hline Variation interval & $\mathrm{X}_{1}$ & 10 & 1.4 & 100 \\
\hline Upper level & + & 40 & 9.4 & 1150 \\
\hline Lower level & - & 20 & 6.6 & 950 \\
\hline
\end{tabular}

After statistical analysis, the equations have the following form:

$$
\begin{aligned}
& Y_{\gamma}=1.285-0.098 X_{1}-0.570 X_{3} \\
& Y_{r}=108.13-24.13 X_{2}-80.32 X_{3}
\end{aligned}
$$

When checking the suitability of the above equations by Fisher's criterion, they all became adequate.

Analysis of equations (1) and (2) shows that within the limits of variation of the variables, the burning temperature, and shale consumption has the most significant effect on the average density of the aggregate, and the effect of the burning temperature is six times greater than the consumption of shale. As the strength of the aggregate decreases, the burning temperature and the alkali silicate consumption increase.

Fig. 7, 8 shows a graphical interpretation of the obtained dependencies.

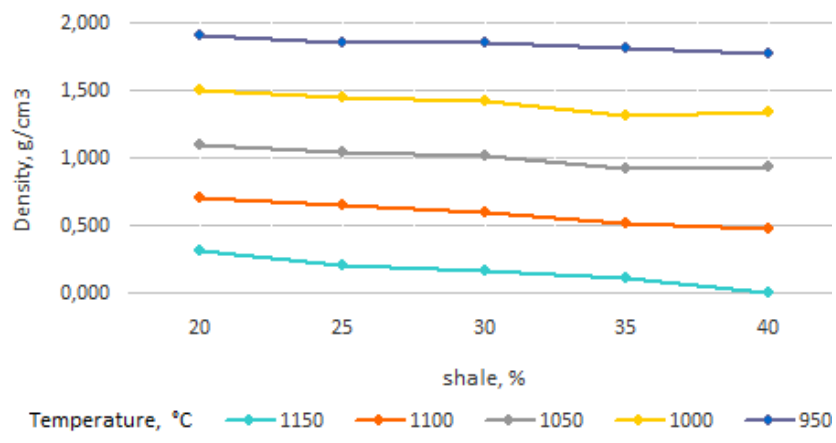

Fig. 7. Influence of technological factors on the average density of the aggregate.

\section{Properties of porous waste aggregate}

To obtain a complete characterization of a material and to identify its behavior in concrete, detailed studies of its properties, structure, and phase composition are required.

Such studies are essential because of the specifics of the raw materials used, allowing us to assume that we have an aggregate that differs from other aggregates similar in technology and shape in terms of structure.

The aggregates obtained both in a laboratory and in industrial conditions were subjected to research. The general view of the porous aggregate granules from the MBC wastes showed in Fig. 9.

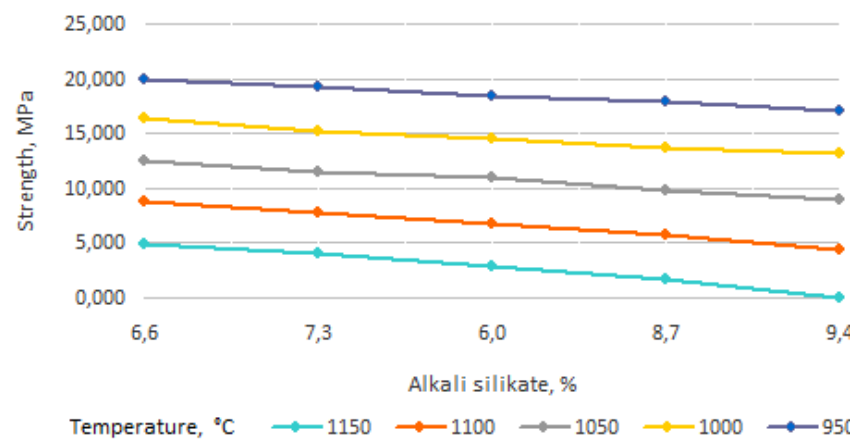

Fig. 8. Influence of technological factors on the strength of the aggregate.

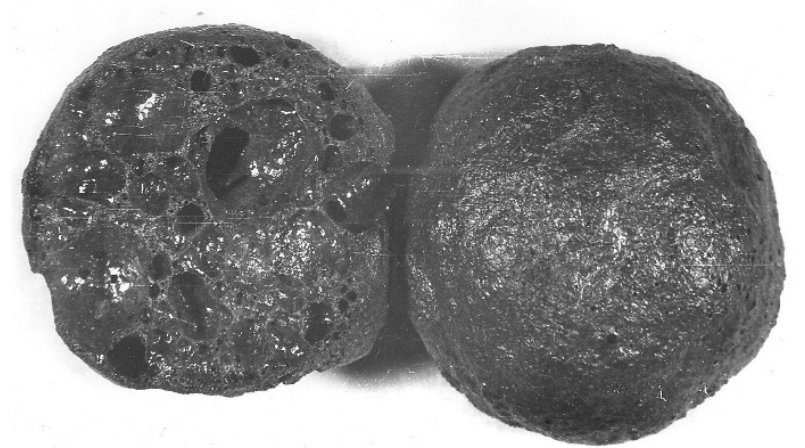

Fig. 9. General view of aggregate granules, $d=25 \mathrm{~mm}$.

The samples of the obtained porous aggregates of dark brown color differ little from each other and have a largeporous structure with cavities. The pores are generally round, 250-1000 microns in size. The surface of the aggregate is partially melted and differs from the inner layers in its lower porosity. The absence of a dense sintered crust on the new aggregate's surface is expected to increase adhesion to the cement stone, ultimately leading to increased concrete strength.

The images were taken with a Scanning Electron Microscope (SEM) to show a porous aggregate structure from MBC wastes (Fig. 10). There is a different size of porosity of the material. The pores have a smooth surface, and the surface of the chipped partitions between the pores is glassy (homogeneous).

The nature of pore formation is the peculiarity of the new aggregate structure. The swelling of the pyroplastic melt causes this process due to the release of $\mathrm{CO} 2$ from the pellet volume.

$\mathrm{X}$-ray analysis of granules burnt at a temperature of $1000{ }^{\circ} \mathrm{C}$ (Fig. $11 \mathrm{a}$ ) shows a significant decrease in $\beta$-lines of quartz, the appearance of lines of mullite, corundum, albite, nepheline and minerals of zeolite structure:

- mullite - $3 \mathrm{Al}_{2} \mathrm{O}_{3} \cdot 2 \mathrm{SiO}_{3}$ with $\mathrm{d} / \mathrm{n}=53 ; 38 ; 35 ; 33.8$; $28.8 ; 26.8 ; 25.4 ; 24.9 ; 23 ; 22 ; 21.2 ; 16.9 ; 15.2 \mathrm{m \mu}$;

- corundum $-\alpha-\mathrm{Al}_{2} \mathrm{O}_{3}$ with $\mathrm{d} / \mathrm{n}=34.8 ; 25.5 ; 24 ; 20.8$; $17.4 ; 16.0 ; 15.4 ; 15.08 \mathrm{m \mu}$;

- albite - $\mathrm{Na}_{2} \mathrm{O} \cdot \mathrm{Al}_{2} \mathrm{O}_{3} \cdot 6 \mathrm{SiO}_{z}-$ high-temperature modification with $\mathrm{d} / \mathrm{n}=32.1 ; 25.1 \mathrm{~m} \mu$;

- nepheline $-\mathrm{Na}_{2} \mathrm{O} \cdot \mathrm{Al}_{2} \mathrm{O}_{3} \cdot \mathrm{SiO}_{2}$ with $\mathrm{d} / \mathrm{n}=70.7 ; 40.4$; 
$31.8 ; 26.8 \cdot \mathrm{m} \mu$;

- $\quad$ zeolites with $\mathrm{d} / \mathrm{n}=26.1 ; 16.68 ; 15.07 \cdot \mathrm{m} \mu$.
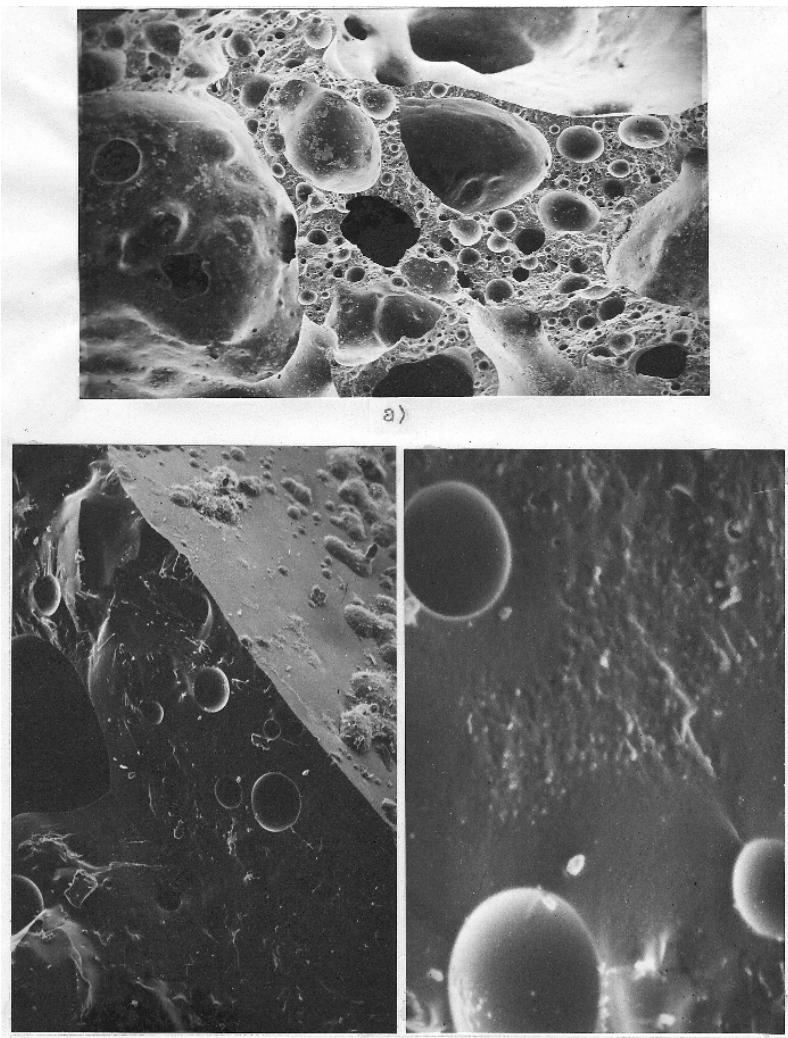

б)

B)

Fig. 10. Aggregate structure image with SEM: a) general view, magnification $45 x$; b) chipped partition, magnification $700 x$; c) chipped partition, magnification $3000 x$.

Thermographic studies of the raw granules burnt at a temperature of $1000{ }^{\circ} \mathrm{C}$ showed (Fig. 12) the presence of the weak endothermic effects with maximum temperatures of $58,249,590$, and $800{ }^{\circ} \mathrm{C}$.

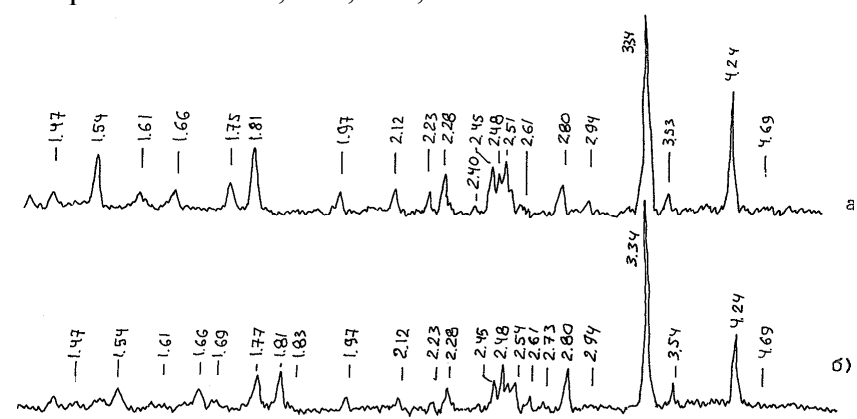

Fig. 11. Radiograph of the burnt masses: a) burnt at $1000^{\circ} \mathrm{C}$; b) burnt at $1150^{\circ} \mathrm{C}$.

All four weak endoeffects are probably associated with the polymorphic transformations in an insignificant part of silica from its total amount into phase varieties of quartz sequentially with a decrease in the temperature of endoeffects: $\alpha$-tridymite $\rightarrow \alpha$-quartz $\rightarrow \beta$-quartz $\rightarrow \beta$ cristobalite $\rightarrow \gamma$-tridymite. According to the X-ray phase analysis, $\beta$-quartz remains the most representative modification. When burnt, the lines of $\gamma$-tridymite with $\mathrm{d} / \mathrm{n}=43.9$ appear; $41.2 ; 37.3 ; 24.9 ; 16.9 ; 16.2 ; 15.9 ; 15.28$ $\mathrm{m} \mu$.

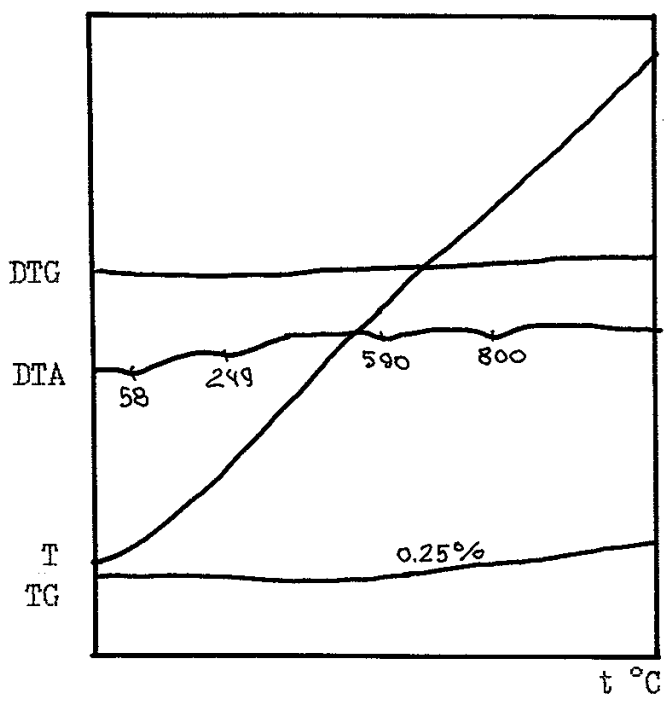

Fig. 12. Thermogram of the aggregate burnt at the temperature of $1100^{\circ} \mathrm{C}$

When calcinated up to $800{ }^{\circ} \mathrm{C}$, the weight loss was $0.25 \%$, which is within the experimental error. Perhaps such weight loss is due to the adsorbed water after burning. This fact may correspond to a weak endothermic effect at a maximum temperature of $58^{\circ} \mathrm{C}$.

An increase of the burning temperature to $1150{ }^{\circ} \mathrm{C}$ (Fig. 12 b) leads to an increase in mullite, corundum, $\gamma$ tridymite, and aluminosilicates of the zeolite structure and albite.

According to the methodology of State standard GOST 9758-2012 (Porous inorganic fillers for construction works, Test methods), the research was carried out. An artificial porous aggregate from MBC wastes obtained in experimental industrial conditions were tested. The test results are presented in the table. 2 .

For pilot production of aggregate used a mixture of mining waste and shale in a ratio of $4: 1$ by weight; the consumption of liquid glass is $8 \%$ of the weight of dry components and firing temperature $1100{ }^{\circ} \mathrm{C}$ for 15 minutes.

As table 2 shows, the tested aggregate meets the requirements of GOST 9757-90 (Artificial porous gravel, crushed stone, and sand. Technical conditions) and belongs to the highest quality category.

Table 2. Physical and mechanical properties of porous aggregate from $\mathrm{MBC}$ wastes.

\begin{tabular}{|l|c|c|c|c|}
\hline \multirow{2}{*}{ Indicators } & \multirow{2}{*}{$\begin{array}{c}\text { Units of } \\
\text { measurement: }\end{array}$} & \multicolumn{3}{|c|}{ fraction, $\mathrm{mm}$} \\
\hline Density & $\mathrm{g} / \mathrm{cm}^{3}$ & 2.95 & 2.95 & 2.95 \\
\hline Bulk density & $\mathrm{kg} / \mathrm{m}^{3}$ & 1150 & 1100 & 1000 \\
\hline Average density of grains & $\mathrm{g} / \mathrm{cm}^{3}$ & 1.93 & 1.90 & 1.89 \\
\hline Porosity of grains & $\%$ & 39.0 & 42.0 & 45.0 \\
\hline Moisture & $\%$ & 0.70 & 0.68 & 0.74 \\
\hline Water absorption per hour & $\%$ & 5.20 & 6.50 & 8.80 \\
\hline $\begin{array}{l}\text { The compression strength } \\
\text { of the aggregate in the } \\
\text { cylinder }\end{array}$ & $\mathrm{MPa}$ & 6.50 & 5.80 & 4.96 \\
\hline Softening coefficient & - & 0.98 & 0.96 & 0.94 \\
\hline Grain shape coefficient & - & 1.15 & 1.20 & 1.25 \\
\hline Frost resistance & cycle & $>100$ & $>100$ & $>100$ \\
\hline
\end{tabular}


The strength of lightweight concrete is not only a function of the consumption and strength of the binder, the consumption of porous aggregates, but it is also determined by the structure and composition of the contact layer between them. Due to the difference between the obtained porous aggregate from other known ones, the processes occurring at the border with the cement stone can proceed differently and lead to hydrated compounds with different specific surface areas and porosity. Ultimately, this will lead to a change in the binder's porosity, concrete structure, and physical and technical properties.

A cement stone's contact zone with a large porous aggregate (Fig. 13) has the form of a winding line exactly repeating the granule relief, providing a tight and robust contact.

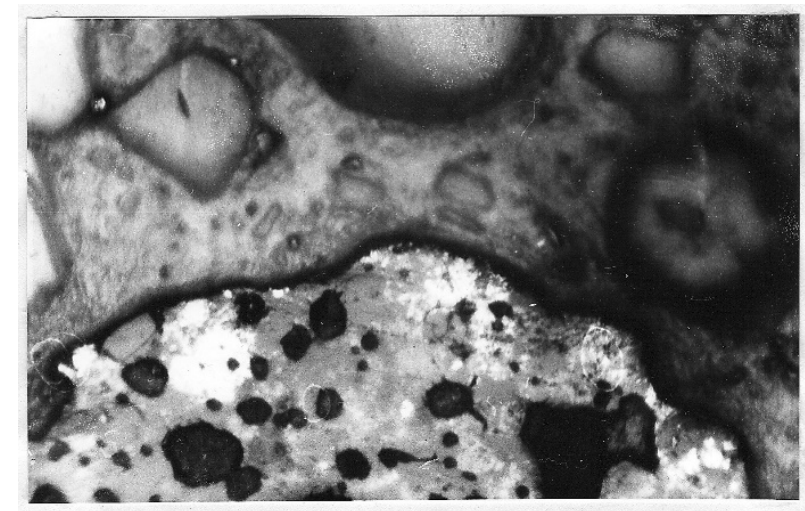

Fig. 13. Contact zone of new porous aggregate with cement stone.

The thermogram of the cement stone from the intergranular space (Fig. 14 a) showed the presence of four endoeffects with a maximum temperature of 155 , 521,663 , and $818^{\circ} \mathrm{C}$.

The temperature of $155{ }^{\circ} \mathrm{C}$ corresponds to the dehydration of the high sulfate form of calcium hydrosulfoaluminate in the presence of gypsum or lowbasic calcium hydrosilicates in the binder. A temperature of $521{ }^{\circ} \mathrm{C}$ corresponds to the dehydration of tobermoritetype hydrosilicates, and $818{ }^{\circ} \mathrm{C}$ corresponds to the decomposition of $\mathrm{CaCO}_{3}$. When calcinated up to $400{ }^{\circ} \mathrm{C}$, the total weight loss was $11 \%$.

Thermographic studies of the contact zone, burnt granules (the binder) showed (Fig. $14 \mathrm{~b}$ ) the presence of seven endoeffects with temperatures at maximum: 110 , $228,480,584,712,784,849^{\circ} \mathrm{C}$. The endothermic effect at $110{ }^{\circ} \mathrm{C}$ corresponds to the dehydration of the threesulfate form of calcium hydrosulfoaluminate or calcium hydrosilicates of a hydrating binder; $480{ }^{\circ} \mathrm{C}$ corresponds to the dehydration of $\mathrm{Ca}(\mathrm{OH})_{2} ; 712{ }^{\circ} \mathrm{C}$ - dehydration of tobermorite type hydrosilicates - $\mathrm{CSH}(\mathrm{B}) ; 784{ }^{\circ} \mathrm{C}-$ $\mathrm{CaCO}_{3}$ dissociation. At the maximum temperatures of 849, 584, and $228{ }^{\circ} \mathrm{C}$ weak endoeffects correspond to silica transformations into its polymorphic modifications described above.

In the contact zone, water was sucked into the granule body. Therefore, the weight loss upon calcination up to $800{ }^{\circ} \mathrm{C}$ was $1.5 \%$. With a lack of water, hydration hardening occurs in the binder particles' surface layers adjacent to the granule. The conditions for forming hydrosilicates of the tobermorite type of a high crystallization degree are created (the temperature shift of the maximum endothermic effect from $633{ }^{\circ} \mathrm{C}$ for the binder $712{ }^{\circ} \mathrm{C}$ in the contact zone).

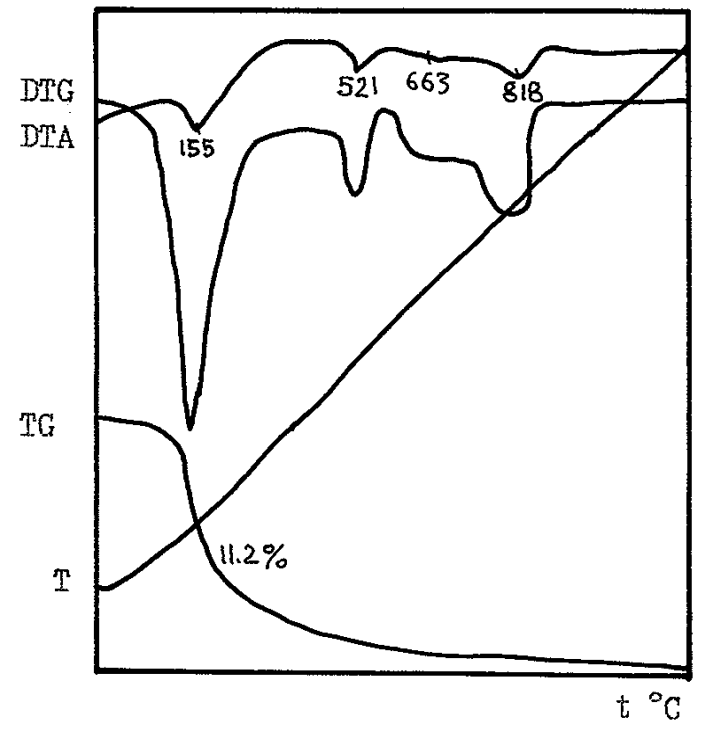

a)

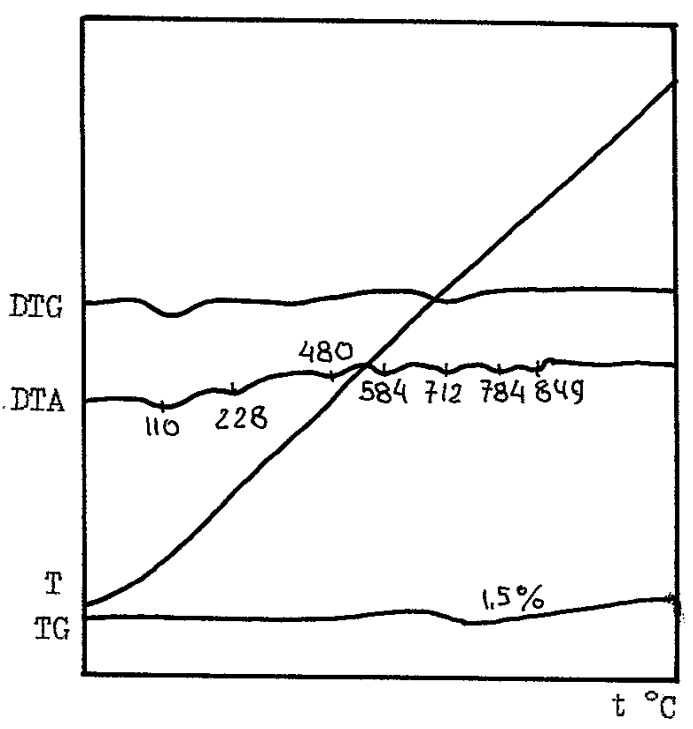

б)

Fig. 14. Thermogram of cement stone: a) in the intergranular space; b) from the contact layer.

The microhardness measurement method was used to study the micro-strength properties of the contact zone. The results have shown that the microhardness of the aggregate $(9000 \ldots 11000 \mathrm{MPa})$ exceeds the microhardness of the cement stone in the contact zone $(4000 \ldots 6000$ $\mathrm{MPa}$ ), and the microhardness of the contact zone is higher than that one of the cement stone in the intergranular space $(1500 \ldots 2000 \mathrm{MPa})$.

\section{Conclusions}

- To obtain a porous filler, the most optimal is raw mixtures containing $20 \ldots 40 \%$ shale and $6 \ldots 10 \%$ liquid glass, fired at a temperature of $950 \ldots 1150{ }^{\circ} \mathrm{C}$.

- Mathematical models have been obtained that reflect the influence of technological factors on the volume, density, and strength of porous aggregates from the 
waste of mining and processing plants.

- The physical and mechanical properties of the obtained porous filler, characterized by high mechanical strength, have been determined. The filler meets the requirements of the standards and belongs to the highest quality category.

- The filler has a porous structure with a predominance of pores $250-1000 \mu \mathrm{m}$ and is composed of mullite, corundum, albite, nepheline, and minerals of zeolite structure.

- In the contact layer between the aggregate and the cement stone, a chemical interaction occurs with the formation of hydrosilicates of the tobermorite type, contributing to strengthening and intergrowth with the cement stone.

\section{References}

1. Satish, C., Leif, B. Lightweight Aggregate Concrete. Noyes Publications, New York, 2002.

2. Persson, B. Compatibility between flooring materials and concrete. Mat. Struct. 35, 170182 (2002). https://doi.org/10.1007/BF0253358 6

3. Chandra, S. and L. Berntsson. Lightweight aggregate concrete. Science, technology, and applications. (2003).

4. Purnell, P. Material nature versus structural nurture: the embodied carbon of fundamental structural elements. Environ Sci Technol (2011)

5. Mehta, P. Sustainable cement and concrete for the climate change era - Proceedings of the second international conference on sustainable construction materials and technologies, Università Politecnica Delle Marche, Ancona, Italy (2010)

6. Krivenko, P.V., Pushkareva, K.K., Kochevykh, M.O., Zapovnyuvachi dlya betonu: Pidruchnyk.K.: FADA, LTD, - 399 s. (2001).

7. Rogovoy, M.I., Tekhnologiya iskusstvennykh poristykh zapolniteley i keramiki. - M.: Izd-vo lit. po str-vu, - 319 s. (1974).

8. Elinzon, M.P. Proizvodstvo iskusstvennykh poristykh zapolniteley. - M.: Stroyizdat, - $256 \mathrm{~s}$. (1974).

9. Ivanenko, V.N. Stroitel'nyye materialy i izdeliya iz kremnistykh porod. - K.: Budível'nik, - $120 \mathrm{~s}$. (1978).

10. Chekhov A.P., Sergeyev A.M. Stroitel'nyye materialy na mestnom syr'ye. - Dnepropetrovsk. Promín'. 96 s (1970) 